\title{
Shulha Oleksandr,
}

Postgraduate, Academy of Advocacy of

Ukraine, Senior Special Inspector of the

Chief Investigative Directorate,

Kyiv, Ukraine

\section{LEGAL AND ORGANIZATIONAL ISSUES OF THE APPOINTMENT AND CARRYING OUT LEGAL EXPERT EXAMINATION IN THE CRIMINAL JUSTICE OF UKRAINE}

Paper is devoted to a topical issue, which is important in theoretical and practical application. The issue of the appointment and carrying out forensic expertise in certain categories of criminal proceedings is quite problematic today and has some peculiarities. Since the entry into force of the Criminal Procedure Code of Ukraine (hereinafter - the CPC) in 2012, taking into account recent amendments to the CPC of Ukraine and amendments to the Law of Ukraine "On Judicial Expertise", it should be noted that the issue of appointment and conduction of forensic expertise has passed some positive changes, but there is a number of problems of theoretical and practical nature requiring development and resolution.

Research paper is based on the analysis of the regulations of current criminal procedural legislation and by-laws concerning the topic of the paper, as well as the modern specialized legal literature.

It is noted that forensic expert examination is necessary for the investigation of the majority of "art crimes", however, to date, the development of many aspects of this class of expertise from the theoretical and organizational-legal standpoint is insufficient.

The author suggests ways to improve the legal and organizational aspects of forensic expertise, in particular, the concept of forensic expertise is revealed, and the methods of its implementation are developed; holistic approaches are developed for the identification of new objects of forensic expertise, as well as the structure of expert 
opinion; the issue of creating specialized institutions or units that would conduct forensic expert studies is considered. Given the above mentioned, it can be stated that the paper contains a proper analysis of a number of organizational and legal issues concerning the appointment and conduction of forensic expertise and proposals for their solution.

Keywords: art, forensic inquiry, судово-мистецтвознавча експертиза, expert art critic.

\section{REFERENCES}

1. Hora I.V. (2015) Problemy sudovo-mystetstvoznavchoyi ekspertyzy v sudochynstvi Ukrayiny. "Problems of Forensic Expertise in the Judiciary of Ukraine". Journal of the Academy of Advocacy of Ukraine 4. (29), P.42-49 [in Ukrainian].

2. Piskunova Ye.V. (2013) Kriminalisticheskoye obespecheniye rassledovaniya prestupleniy $\mathrm{v}$ sfere iskusstva: sudebno-iskusstvovedcheskaya ekspertiza. "Forensic Support for the Investigation of Crimes in the Field of Art": Forensic Art Examination: author. diss. ... Cand. Sci. (Law): 12.00.12. Moscow. 29 p. [in Russian].

3. Bondarenko L.K. (2015) Dokazatelstvennoie soderzhaniie sudebno iskusstvovedcheskoi ekspertizy. "Evidence-Based Content of Forensic Art Examination”. Theory and Practice of Forensics 3 (39), 17-22[in Russian].

4. The Criminal Procedure Code of Ukraine. The Verkhovna Rada of Ukraine (VVR). 2013. No. 9-10, P. 11-12, 13. Art. 88. URL: http://zakon5.rada.gov.ua/laws/show/4651-17 (date of application: 30.10.2019) [in Ukrainian].

5. Forensic Examination: Law of Ukraine. The Verkhovna Rada of Ukraine (VRU). 1994. No 28. Art. 232. URL: http://zakon5.rada.gov.ua/laws/show/4038-12 (date of application: 30.10.2019) [in Ukrainian].

6. On approval of the Instruction on the appointment and conduct of forensics and expert studies, scientific and methodological recommendations on the preparation and appointment of forensics and expert studies: Order of the Ministry of Justice of Ukraine. No 53/5 dated 08.10.1998 (as amended in accordance with Orders 
of the Ministry of Justice: No 144/5 dated 30.12.2004; No 59/5 dated 10.06.2005; No 126/5 dated 29.12.2006; No 1198/5 dated 15.07.2008; No 965/5 dated 01.06.2009; No 1950/5 dated 26.12.2012; No 1350/5 dated 27.07.2015; No 1420/5 dated 26.04.2017). URL: http://zakon5.rada.gov.ua/laws/show/z0705-98/page (date of application: 30.10.2019) [in Ukrainian].

7. Mystetstvoznavchi doslidzhennia (doslidzhennia u sferi suspilnoi morali): prohrama pidhotovky pratsivnykiv Ekspertnoyi sluzhby MVS Ukrainy za ekspertnoiu spetsialnistiu 15.1. "Art Studies (Research in the Field of public Morality): Training Program for the Staff of the Expert Service of the Ministry of Internal Affairs of Ukraine (specialty 15.1)" / compilers A.M. Kostrub, K.V. Novikov. Kyiv: DNDECC of the Ministry of Internal Affairs of Ukraine, 2012. 34 p. [in Ukrainian]. 